\title{
Executive Jurisdiction of Realizing Security Interests Cases
}

\author{
Li Linqi \\ Henan Normal University School of Law \\ Xinxiang, China \\ lilinqi726@126.com
}

\author{
Shen Yuanyuan \\ Henan Normal University School of Law \\ Xinxiang, China \\ 807659544@qq.com
}

\begin{abstract}
The request for compulsory execution by the people's court is the purpose of the applicant's initiation of the procedure for realizing the security interests. The particularity of execution in realizing security interest cases requires scientific and reasonable rules for the executive jurisdiction. However, the provisions of the new "Civil Procedure Law" and "Judicial Interpretation of Civil Procedure Law" on the executive jurisdiction over the realization of security interests cases are too vague to provide specific guidance for realizing the execution application of security interests cases in judicial practice. Following the basic principles conducive to applying for the execution by security interest holders and taking execution measures by the people's courts, and combining certainty and flexibility, the executive jurisdiction of the security interests cases in China should be mainly based on the grass-roots people's court where the property is located, and make appropriate adjustments to regional jurisdictions for special situations, while the special people's court may govern cases related to the realization of security interests.
\end{abstract}

Keywords-Security interest; Licensing ruling; Application for execution; Executive jurisdiction; Location of property

\section{INTRODUCTION}

"Winning the judgement is only the first step in achieving the legitimate interests." [1] For non litigation cases such as the realization of security interests cases, the meaning of execution is particularly important. Because the applicant's application for realizing the security interest is not to ask the people's court to resolve the relevant substantive disputes, but to request the people's court to make an auction or sell the ruling of the secured property to obtain the execution name, and apply for the compulsory execution of people's court under the name of the execution, thereby realizing security interest quickly and conveniently. In realizing security interest cases, after the people's court has made a licensing ruling, the applicant can directly apply for the execution procedure on the basis of the ruling. When the applicant starts the execution procedure, the first question is to which people's court to apply. For the executive jurisdiction of realizing security interests cases, the "Civil Procedure Law" did not make provisions. Although the "Judicial Interpretation of Civil Procedure Law" made a provision, it is more principle. The principle of the executive jurisdictional provisions in realizing security interest cases has led to a certain degree of chaos in judicial practice. Therefore, the study of the executive jurisdiction of realizing security interest cases is conducive to the realization of the value and

This study was financially supported by the National Social Science Fund of China (Grant No.15BFX162), one of the achievements of Dr. Start-up project of Henan Normal University (Grant No. qd15104). function of the non-lawsuit proceedings system of the security interest, and to the realization of the legal effect of the substantive and procedural norms of the security interest.

\section{THE LEGISLATIVE STATUS OF REALIZING THE \\ EXECUTIVE JURISDICTION OF SECURITY INTEREST CASES}

The so-called executive jurisdiction is the jurisdiction in the execution of the case, that is, the division of labor of enforcement cases within the people's court system. Judging the jurisdiction of execution cases is of great significance for the balanced coordination of the internal work of the people's courts, the exercise of rights holders' right of application, the realization of substantive rights, the guidance and supervision of the higher people's courts, and the maintenance of national sovereignty.

\section{A. General Rules and Defects of Executive Jurisdiction of the "Civil Procedure Law"}

Article 196 and 197 of the "Civil Procedure Law" stipulate the procedural rules for the realization of security interest. According to Article 197 of the "Civil Procedure Law," after the people's court accepts the application for the realization of security interests by the applicant, and through the review, for those that comply with the law, the court shall auction or sell the secured property in accordance with the law. According to the ruling made by the people's court, the parties can apply to the enforcement agency of the people's court for enforcement. Judging from the latter part of the first half of Article 197, the "Civil Procedure Law" only stipulates in principle that the parties can apply to the people's court for execution based on the ruling that the auction of the secured property can be approved or sold, and it does not stipulate the jurisdiction court

China's general provision on the executive jurisdiction is Article 224 of the "Civil Procedure Law." This article stipulates that legally effective judgments or written orders in civil cases, as well as the parts of judgments or written orders that relate to property in criminal cases, shall be executed by the people's court of first instance or the executed property at the same level as the first instance people's court is located. Other legal documents which are to be executed by a people's court as prescribed by the law shall be executed by the people's court of the place where the person subjected to execution has his domicile or where the property subject to execution is located. According to Article 224 of the "Civil Procedure Law," when the civil ruling has become legally effective, the 
enforcement court may be a people's court of the first instance or a people's court at the same level as the court of the first instance. In non-litigation cases, the relationship between the rights and obligations of the parties is usually not subject to substantive investigation, so the court's decision is usually made in the form of a ruling. The procedural requirements of the "Civil Procedure Law" regarding the realization of security interest are non-contentious procedures. The ruling made by the people's court pursuant to this procedure is a non-litigation ruling [2]. However, according to the interpretation of the participating legislators, the "ruling" in Article 224 of the "Civil Procedure Law" is mainly based on the ruling of preservation measures and the prior execution, admitting and enforcing the ruling made by foreign court or arbitration institution [3]. In other words, the general provisions of China's "Civil Procedure Law" concerning the executive jurisdiction do not address the issue of the executive jurisdiction of the rulings made by the people's courts in special procedures, and also the rulings made by the people's courts that grand to auction and sell off the secured properties in the non-contentious procedures for realizing security interests.

\section{B. The Provisions and Insufficiency of "Judicial}

Interpretation of the Civil Procedure Law" Concerning the Executive Jurisdiction over the Realization of a Security Interests Cases

In response to the lack of executive jurisdictional provisions in special procedures of the "Civil Procedure Law," the "Judicial Interpretation of Civil Procedure Law" promulgated in 2015 stipulates the executive jurisdiction of realizing security interest cases in accordance with the general provisions of the "Civil Procedure Law" concerning the executive jurisdiction. Article 462, Paragraph 1 of the "Judicial Interpretation of the Civil Procedure Law" stipulates: "A legally effective execution of a security interest ruling, confirmation of a mediation agreement ruling, and an order for payment shall be made by the people's court where the ruling or payment order is made or the execution property of the same level is located." This paragraph clarifies the executive jurisdiction of the people's court's ruling in special procedures such as the realization of security interest, which can be either the people's court which make the ruling or the people's court in the same location where the property was executed. Although the "Judicial Interpretation of the Civil Procedure Law" stipulates the court of jurisdiction for the execution of security interests, it adopts the "... or ..." legislative rules, which have no clear and exhaustive provisions for the specific issues in the execution of the case. It is difficult to meet the complications in the realization of security interests cases.

\section{CONSTRUCTION OF THE BASIC PRINCIPLES THAT SHOULD BE FOLLOWED IN THE EXECUTION OF JURISDICTION RULES FOR THE REALIZATION SECURITY INTERESTS CASES}

The provisions of the "Civil Procedure Law" concerning the executive jurisdiction over security interests cases are relatively ambiguous. At present, China's judicial practice has not yet established scientific and mature systematic rules regarding the executive jurisdiction over the realization of security interests cases, and it is necessary to follow certain basic principles to realize the executive jurisdiction rules of the security interests cases. These principles are the basis for the establishment of courts for the realization of security interests cases, and they also have a certain guiding role in the application of the parties in the realization of security interests cases.

\section{A. The Principle of Facilitating the Security Interest Holder to Apply for the Execution}

In a sense, the purpose of the applicant's initiation of the procedures for realizing security interest is to apply for enforcement by the people's court. In the case of realizing security interest, after the people's court made a licensing ruing, auctioning and selling off the secured property has been confirmed, and what the enforcement procedure needs to do is to ensure that the case can be implemented in a timely and effective manner. Therefore, it is the first principle to facilitate the security property right holders to apply for implementation the enforcement in the construction of realizing the jurisdiction of security property rights cases.

\section{B. The Principle of Facilitating the People's Court to Adopt the Execution Measures}

The successful execution of a security interests cases are inseparable from the effective execution measures taken by the people's court to seal up and detain the execution object. Otherwise, it is very likely that the execution time will be delayed, so that the executor will have the opportunity to evade his obligations and damage the interests of the security interests holders. Therefore, facilitating the people's court to take execution measures is an important principle that should be followed in the construction of the executive jurisdiction rules for the realization of security interest cases.

\section{The Principle of Combining Certainty and Flexibility}

The system of security interests in China is rich and complex, and there are three types of statutory security interests: mortgage, pledge, and lien. The scope of property that can be used to set security is very wide and the ways are various. In the face of a rich and complex system of security interests, in the execution of realizing security interests cases, different cases are bound to involve different types of security interests and different kinds of collateral. Even in the same case, it also involves different types of security rights and different kinds of collateral. Therefore, the construction of the executive jurisdiction rules for the realization of security interests cases should follow the principle of certainty and flexibility so that the case can be executed in a timely and effective manner under special circumstances. 
IV. THE PROPOSAl OVER THE CONSTRUCTION OF THE EXECUTION JURISDICTION RULES IN REALIZING THE SECURITY INTERESTS CASES

The "Judicial Interpretation of the Civil Procedure Law" of China adopts "concurrency provisions" for the executive jurisdiction of realizing security interest cases, that is, to be executed by the people's court that made the ruling or the people's court in the place where the enforcement property of the same level is located. This provision is a comprehensive provision, which is based on the revision of the executive jurisdiction and special procedures in the 2007 and 2012 "Civil Procedure Law" and the executive jurisdiction of the payment order in Article 255 of the 1992 "Opinions on Civil Procedure Law," However, according to the provisions of the "Property Law," security interests include mortgages, liens, and pledges, and various types of security interests can be further subdivided according to different standards. In addition, there is the particularity in realizing the ruling execution of security interest cases, that is the inconsistent between the object of execution and the debtor, involving multiple types of collateral security interests and different kinds of collateral, and the subject matter of execution are mostly real estate. Therefore, in order to adapt to the rich and complex system of security interests, in the executive jurisdiction of realizing security interests cases, a scientific, reasonable and operative execution jurisdictional rule must be designed according to the characteristics of realizing the security interests cases, so as to achieve the standardization of the execution of the ruling of the security interests cases.

\section{A. Mainly based on the Grass-roots People's Courts where the Executed Property is located}

For the execution of the ruling on the realization of security interests cases, the grass-roots people's court in the place where the property is to be executed should be the center to determine the executive jurisdiction of its ruling. The grade jurisdiction of execution is the division of executive power in longitudinal direction, the realization of the security interests cases should be referred to the grass-roots people's court, and the first instance final trial, therefore, the execution of the case should be under the jurisdiction of the grass-roots people's court. The territorial jurisdiction of the execution is the division of the executive power in the horizontal direction and the further implementation of the grade jurisdiction. Although China's security interest system is rich and complex, the types of security interests and types of collateral are diverse, and the registration requirements for the establishment of various types of security interests are specific, but in general, the territorial jurisdiction of the execution should be determined mainly by the people's court where the property is located.

Jurisdictional courts that determine the realization of security interests cases based on the execution of the grassroots people's court in the place where the property is executed can meet the needs of various types of security interests cases. For the real estate mortgage rights case, there is generally no dispute because the location of the property and the place of registration are usually within the same people's court jurisdiction. For the realization of the case of chattel mortgage and floating mortgage, it can be registered or not be registered, so it is more appropriate for the people's court where the property is located to have the jurisdiction. The territorial jurisdiction of the execution of a pledged case should distinguish between the pledge of movables and the right of pledge, and the pledge of the movable property is under the jurisdiction of the people's court where the executed movable property is located; in the pledge of rights, the securitization rights of the vouchers of rights, such as the deposit sheet, the cheque, the exchange ticket, the promissory note, the bond, the bill of lading, the warehouse receipt, etc. The place of the certificate of rights can be understood as the place where the secured property is located, and the pledge is generally established from the time of delivery of the voucher, [3] and therefore, it may also be under the jurisdiction of the court where the property is executed. In the realization of a lien case, the lien as a statutory security interest, the creditor's possession of the debtor's property is a prerequisite for its establishment and ever-existing, and the lien has a non-registered property, so the execution of the realization of lien case should be governed by the people's court where the movable property is executed.

\section{B. Make Appropriate Adjustments to Territorial Jurisdictions for Special Situations}

Since the realization of the maximum amount mortgage case has many ambiguities in the guarantee, the execution of the case may be governed by the people's court where the property is executed, or it may be under the jurisdiction of the people's court of the security interest registration; For realizing the property rights without right certificate in the right pledge case, the establishment of pledge right must be registered. Where the pledge is only registered in the security interest, the execution of the case shall be governed by the people's court where the security interests are registered.

It should be noted here that, in the case of the realization of security interest, the place of the secured property is not consistent with the that of the registration of the security interest, if the guarantor of the security interest or other person who entitled to request the realization of the security interest submits an application for the realization of the security interest to the grass-roots people's court where the security asset is located, and the court makes a ruling that allows to auction and sell off the secured asset. Then, if the applicant can apply for compulsory enforcement to the grass-roots people's court where the security interest is registered in accordance with the jurisdiction? The author believes that at this time, the grassroots people's court where the security property is registered cannot execute jurisdiction and accept the applicant's enforcement application. The reason is a guarantor of a security interest or any other person who has the right to ask for the realization of the security interest has submitted an application for realizing the security interest to the grass-roots people's court in where the security asset is located. After obtaining the execution basis, the application for execution is again transferred to the grass-roots people's court where the security property is registered, that is unconventional, incomprehensible, and contrary to the legislative purpose of realizing the security interest with high efficiency, speed, and low cost. [5]Furthermore, according to the provisions of the "Judicial Interpretation of Civil Procedure Law," the execution court for realizing the security interest ruling is the people's court that 
made the ruling or the people's court where the execution property at the same level as the ruling court was made. Although the grassroots people's court is at the same level as the people's court that made the ruling, it is neither the "people's court making the ruling" nor the "people's court in the place where the property is executed." Therefore, there is no execution jurisdiction.

\section{Special People's Courts may Govern Cases Related to Their Execution of Security Interests}

There is a dispute between the academic and substantive departments as to whether a special people's court has jurisdiction over cases of realizing security interests. The opposing view is that Article 196 of the "Civil Procedure Law" stipulates that the application for the realization of security interest shall be submitted by the applicant to the grass-roots people's court in the place where the secured property is located or where the security right is registered in accordance with the Law on Real Rights. The maritime court is not a grassroots people's court and therefore cannot hear such cases. [6]The supportive view is that the maritime court, as a specialized court, hears ordinary procedures, summary procedures and special procedures involving maritime maritime merchants, and the trial is the first instance. The provisions of Article 196 of the Civil Procedure Law do not exclude the special jurisdiction of the maritime court. Therefore, the maritime court accepts applications for the realization of ship mortgage rights and other cases are in line with the law and should be accepted [7].

We believe that, due to the speciality of maritime affairs and other cases, the particularity of the cases under the jurisdiction of the special people's court and the "Civil Procedure Law" is a general law and "Maritime Maritime Law" is a special law. Therefore, cases involving the realization of security interests that are within the scope of the jurisdiction of the exclusive court may be governed by the special people's courts [8]. Article 363 of the "Judicial Interpretation of Civil Procedure Law" provides that if a case for the realization of a security interest falls within the jurisdiction of a special people's court, such as a maritime court, it shall be under the jurisdiction of a special people's court. This provision solves the problem of the special court which is at the same level as the "Intermediate People's Court" if belongs to the "grass-roots court," and if can accepts cases of realizing security interests. According to Article 462, Paragraph 1 of the "Judiciary Interpretation of Civil Procedure Law," the legally effective enforcement of a security interest ruling may be executed by the people's court which makes the ruling. Therefore, special people's courts may administer the cases in which they try to execute security interests.

\section{CONCLUSION}

In specific cases, the effective execution of the people's court's judgments is the basic principle of justice for the parties especially the successful parties in the case. If the case is to be effectively executed, it must have a scientific and reasonable rule of executive jurisdiction. This article, through the analysis of the present situation of legislation over the realization of the jurisdiction of security interests cases, exploring the basic principles of reconstructing the executive jurisdiction rules for realizing security interests cases, and specifies and improves specific measures in the executive jurisdiction rules of the security interests cases. And to facilitate the applicant to apply for the execution, promote the execution work of the people's court, ensure that the people's courts have adequate execution in the execution, and establish the authority of the judiciary and to enhance the credibility of the judiciary.

\section{REFERENCES}

[1] Peter Kaye, John Wiley, and Sons, "Methods of Execution of Orders and Judgments in Europe," 1996, pp.145.

[2] Li Linqi: "The Procedural Nature of Realizing Security Interests in China," Journal of Hunan University of Science \& Technology (Social Science Edition), 3rd ed, 2015. (In Chinese)

[3] Civil Law Office of Legislative Affairs Commission the Standing Committee of the National People's Congress, "The Interpretation and Application of Civil Procedure Law of the People's Republic of China," People's Court Press, 2012, pp.362. (In Chinese)

[4] Li Xiangbo, "Relevant Legal Issues in the Application of the Procedure for the Realization of Security Interests - Centered on Articles 196 and 197 of the New Civil Procedure Law," Journal of Law Application, 8rd ed, 2014. (In Chinese)

[5] Jiang Bixin, "Lecture on New Civil Procedure Law," Law Press · China, 2012, pp.207. (In Chinese)

[6] Wu Yongqi: "The Procedures for Realizing Security Interests Don't Apply to the Realization of Ship Security Interests," People's Court Daily, 2013. (In Chinese)

[7] Xu Junqiang, Chen Yongcan: "On Non-litigation Procedures for Realizing the Mortgage of Ships," Chinese Journal of Maritime Law Research, 1rd ed, 2014. (In Chinese)

[8] Li Linqi, "Research on Non-litigation Cases of Realizing Security Interest Cases,” Sichuan University Press, 2017, pp.30. (In Chinese) 